\title{
Erratum to: Professional Practice as Processes of Muddling Through: a Study of Learning and Sense Making in Social Work
}

\author{
Gunilla Avby
}

Published online: 27 November 2014

(C) Springer Science+Business Media Dordrecht 2014

\section{Erratum to: Vocations and Learning (2014) DOI 10.1007/s12186-014-9123-y}

The published article unfortunately contained a mistake as captions for figures 1 and 2 were interchanged. However, it has been addressed and is not anymore present in the published copies of the article. The figure captions were corrected as follows:

Fig. 1 Event list linked to ongoing processes; the five chosen events are outlined Fig. 2 Five suggested learning opportunities are indicated in the connection of activities and work processes

The online version of the original article can be found at http://dx.doi.org/10.1007/s12186-014-9123-y.

G. Avby $(\bowtie)$

Department of Behavioural Sciences and Learning, Linköping University, SE-581 83 Linköping, Sweden e-mail: gunilla.avby@liu.se 